\title{
兵庫県南部地震時の神戸市内における基盤地震動および地盤増幅特性 BEDROCK MOTIONS AND SITE AMPLIFICATIONS IN KOBE CITY DURING THE 1995 HYOGO-KEN NANBU EARTHQUAKE
}

\author{
永野正行*, 大野晋**, 古山田耕司*, 加藤 研一*** \\ Masayuki NAGANO, Susumu OHNO, Kohji KOYAMADA \\ and Kenichi KATO
}

\begin{abstract}
This study investigates bedrock motions on an outcrop of Rokko granite rock and site amplification characteristics due to deep irregular underground structures in Kobe City during the 1995 Hyogo-ken Nanbu earthquake. Six sections normal to Rokko Fault are modeled based on 2-D seismic profiles determined from geological surveys. Peak velocities of bedrock motions deconvolved from 6 records show almost the same level, $50-60 \mathrm{~cm} / \mathrm{s}$, while those on an outcrop of Osaka group are $86-137 \mathrm{~m} / \mathrm{s}$. Ground motions at sea side area can be well simulated, indicating that bedrock motions are expected to be properly evaluated. In soil responses on Osaka group, the large amplifications can be commonly seen at area about $1 \mathrm{~km}$ away from basin edge to seaside, while the transfer functions from the bedrock are varied according to the bedrock shapes. Distributions of maximum responses are accountable for the distributions of damaged structures.
\end{abstract}

Keywords: Hyogo-ken Nanbu Earthquake, bedrock motion, site amplification, deep irregular underground structure,2-D finite element method, simulation analysis 兵庫県南部地震、基盤波、地盤増幅、深部不整形地下構造、2 次元FEM、シミュレーション解析

\section{1.はじめに}

1995 年兵庫県南部地震では、神戸市街地を中心として東西に 帯状に分布する被害地域、いわゆる震災の帯が形成され、多数の家 屋等が壊滅的な被害を受けた。震災の帯地域での大被害の主原因と して、神戸市街地直下の媣部不整形地下構造による地震動増幅 が指摘された。地唒直後より神戸市内では反射法探査等の地盤調査 が精力的に行われ、最近ではより精度の高い地盤情報が公開されて いるの。まま強震記録の公開 7\%飽和記録の復元りにより、被害解 明のための情報環境が整いつつある。これらの情報を基に震源から 観測点に至る 3 次元解析を行った研究 1011)も行われているが、計算 機能力の限界や震源モデル ${ }^{12)}$ の推定精度の限界により $0 \sim 1 \mathrm{~Hz}$ 前後 の検討にとどまっている。特に兵庫累南部地震で重要となる $1 \mathrm{~Hz}$ 前 後の振動数成分の定量的な評価が不十分な場合もあり、実際の被害 との対応の検郡や、強、非線形举動が予測される軟弱表層地盤の举 動予測が困難となる ${ }^{13)}$ 。一方、2 次元解析では震源断層からの複雑 な入射場や 3 次元地形効果は考慮できないが、観測記録をコント ロールモーションとして用いることにより、最大值評価を含む地震 動の定量的な評価が可能となる。

神戸市内では同じ段差状の梁部地下構造でも、その形状が東西 方向で微妙に変化することが反射法探查等 のによよ明らかになっ
ている。本論文ではこれらの結果に基づき 2 次元断面を用いた強震 動シミュレーション解析を実施し、基盤波の評価や地盤増幅特性の 検討を行う。解析対象は神戸市内の東西に分布する6つの断層直交 断面であり、解析手法は 2 次元有限要素法(FEM)である。まず神戸 市内 6 地点の強震観測記録を用いて、神戸市直下の大阪層群と六甲 花崗岩の露頭面における基盤波を評価し、最大值と応答スペクトル を比較する。次にこの基盤波を用いて海側の地点での観測記録のシ ミュレーション解析を行い、逆算基盤波の妥当性を検討する。最後 に断層直交6断面における大阪層群上面での最大忘答加速度、速度 分布を算定し、最大応答分布と実際の被害分布との関係を考察する。 川瀬・林 ${ }^{2}$ 、林・川瀬 ${ }^{3}$ は気象台、三宮断面で地震動の定量評価を 含む同様の検討を行っているが、本論文はこれを神戸市内のより広 範囲に適用し一般化したものであり、更に深部地下構造の形状の差 異による地震動の地盤増幅特性の変化を調べたものである。なお本 論文は灘地域 3 断面を対象とした既発表の検討 ${ }^{19}$ に、更に3断面を 追加検討し、上記の各種考察を加えた内容となっている。

\section{2. 解析対象断面と有限要素モデル}

Fig.1 に示す神戸市内の断層方向に直交する 6 断面を解析対象と

\footnotetext{
* 麇島小场砳究基

** 麇自技術研究所

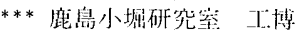

Kobori Research Complex, Kajima Corporation

Technical Research Institute, Kajima Corporation

Kobori Research Complex, Kajima Corporation, Dr. Eng. 


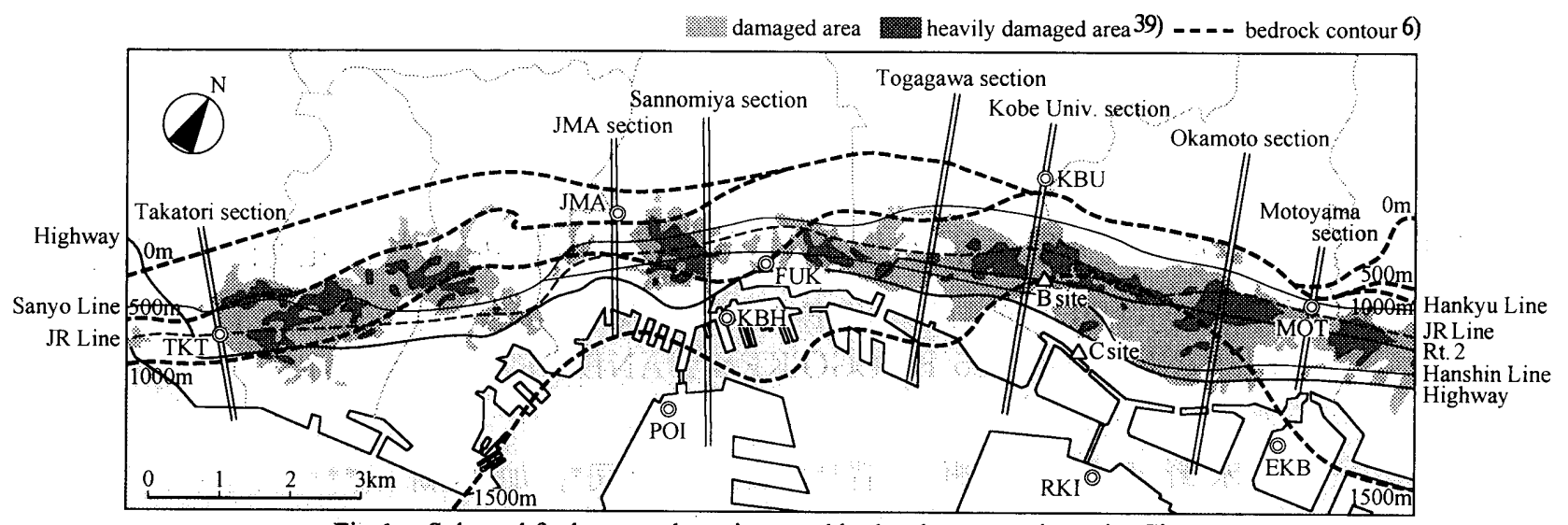

Fig.1 Selected fault-normal sections and bedrock contour in Kobe City

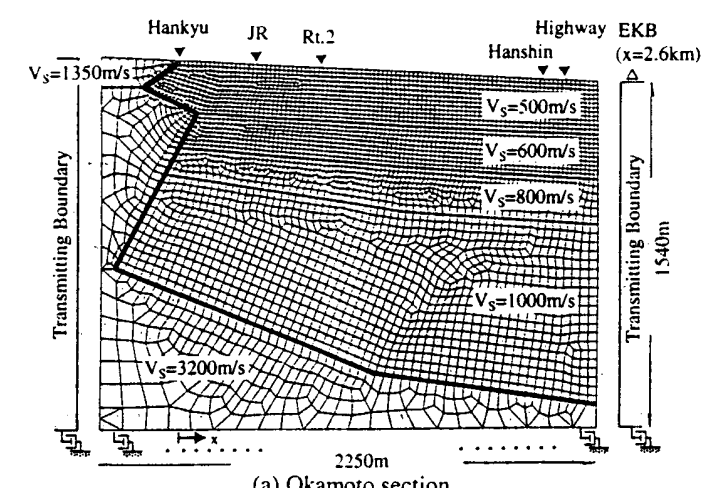

(a) Okamoto section

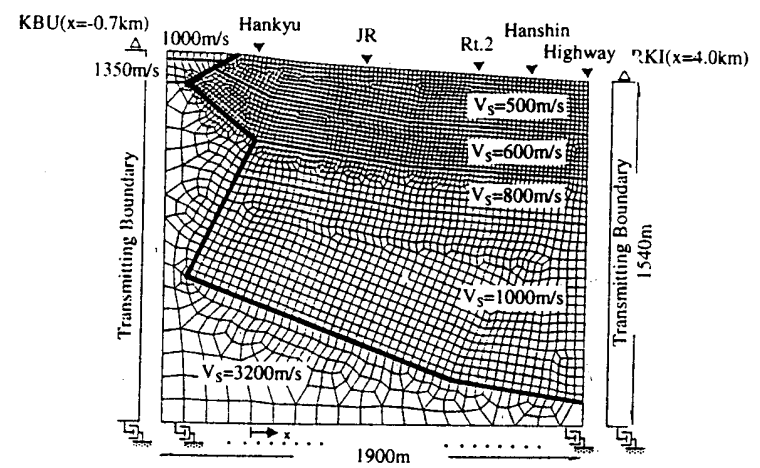

(b) Kobe Univ, section

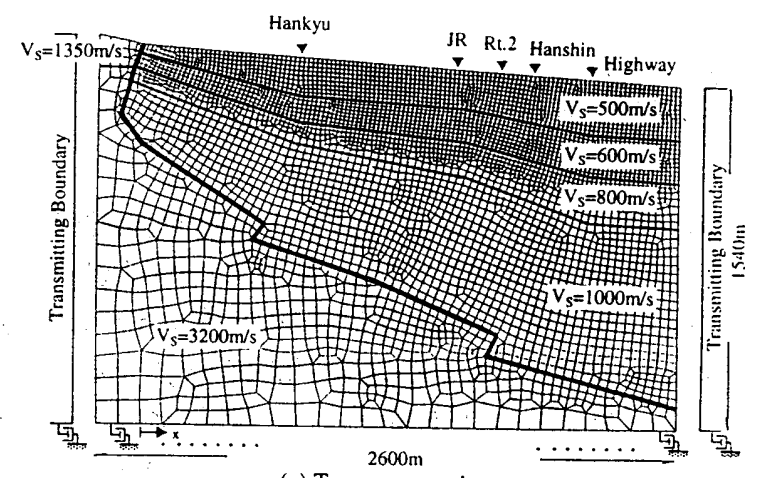

(c) Togagawa section

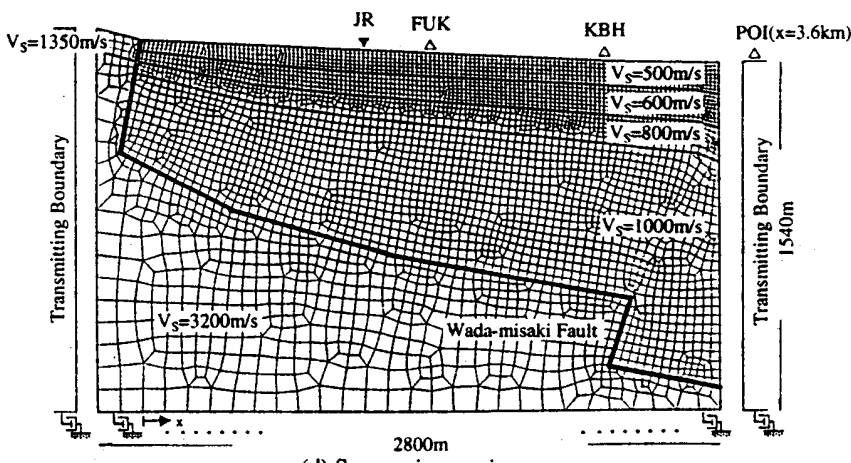

(d) Sannomiya section

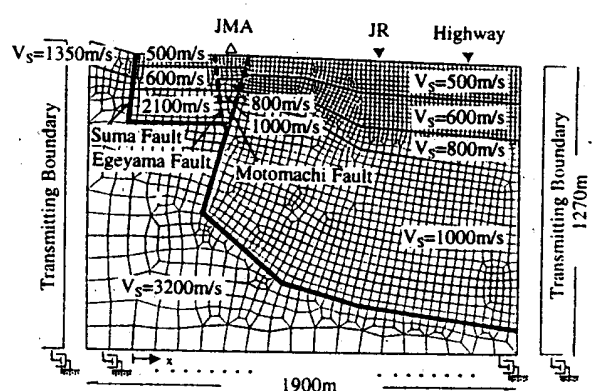

(e) JMA section

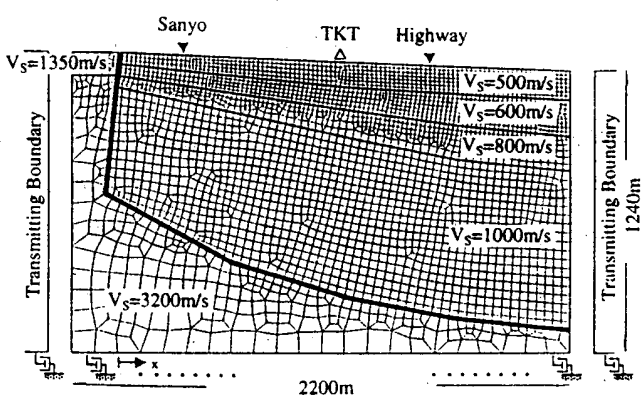

(f) Takatori section

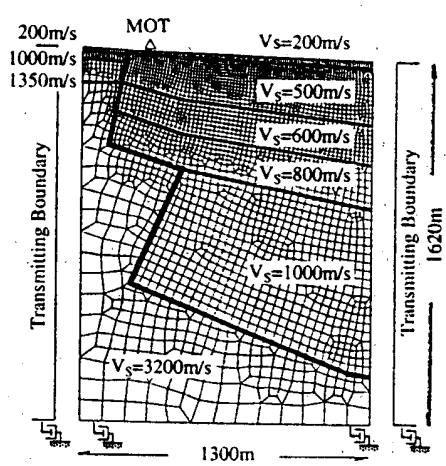

(g) Motoyama section

Fig.2 Finite element meshes of fault-normal sections in deep irregular underground structure

する。東偵から岡本断面、神戸大学断面、都賀川断面、三宮断面、 気象台断面、鷹取断面と呼ぶ。各断面の方向は、六甲山地形の方向 を考虚し、前半の 3 断面に関しては $\mathrm{N} 160^{\circ} \mathrm{E} 、$ 三宮断面、気象台断 面は $\mathrm{N} 150^{\circ} \mathrm{E} 、$ 鷹取断面は $\mathrm{N} 140^{\circ} \mathrm{E}$ とする。作成した 2 次元 FEM モデルを Fig.2 に示す。各断面のモデル化は神戸市内で実施された 反射法探查による地盤情報や基盤の深度コンタ ${ }^{9}$ 、、常時微舅観測
に基づく推定地下構造 190 等に基づき行った。ここでは地表近くの 沖稹層や上部洪積層は取り除き、大阪層群以深の地盤構造をモデル 化する。堆積層の地層構造は、小林ら五による染層ボーリング結果、 香川ら ${ }^{18}$ の推定構造より Table 1 に示寸せん断波速度 $\mathrm{V}_{\mathrm{s}}$ が $500 \mathrm{~m} / \mathrm{s}$ $\sim 3200 \mathrm{~m} / \mathrm{s}$ の 5 層構造とした。地盤の減衰定数は川瀬・林 ${ }^{2 を}$ を参考 に1〜3\%を仮定した。 
Table 1 Soil profile used in 2-D FEM models

\begin{tabular}{|c|c|c|c|c|}
\hline area & $V_{S}(\mathrm{~m} / \mathrm{s})$ & $V_{\mathrm{p}}(\mathrm{m} / \mathrm{s})$ & $\gamma\left(\mathrm{tm}^{3}\right)$ & $\mathrm{h}(\%)$ \\
\hline \multirow{4}{*}{ Osakagroup } & 500 & 1800 & 1.8 & 3 \\
\cline { 2 - 5 } & 600 & 1900 & 1.9 & 3 \\
\cline { 2 - 5 } & 800 & 2200 & 2.0 & 2 \\
\cline { 2 - 5 } & 1000 & 2500 & 2.1 & 2 \\
\hline bechock & 3200 & 5400 & 2.7 & 1 \\
\hline weathered & 1350 & 3100 & 2.2 & 2 \\
\cline { 2 - 5 } rock & 2100 & 4200 & 2.4 & 2 \\
\hline surface(MOT) & 200 & 660 & 1.7 & 5 \\
\hline
\end{tabular}

いずれの断層直交断面もせん断波速度 $\mathrm{V}_{\mathrm{s}}=3200 \mathrm{~m} / \mathrm{s}$ の六甲花崗 岩（以降、基盤と記す）が六甲山麓で落ち込み、海側に徐々に深く なり、その上に大阪層群が堆積寸る形状となっている。岡本、神戸 大学断面では六甲山麓より基盤が $1 \mathrm{~km}$ 程度急激に落ち込む形状を 呈しているのに対し、都賀川断面では基盤の落ち込みが神戸大学、 岡本断面に比べ浅く、基盤が $2 つ の$ 伏在断層を経て海側に徐々に深 くなる。上記 3 断面では海岸線近くの基盤の深さは約 $1.5 \mathrm{~km}$ であ る。三宮断面では六甲山麓で基盤が $600 \mathrm{~m}$ 程度落ち込み、海側に緩 く傾斜する。基盤形状のモデル化には二宮町での温泉ボーリングに よる基盤染度 $724 \mathrm{~m}^{19}$ も参考にした。海岸線付近では和田岬断層の 存在により基盤が再ひ落ち込み、ポートアイランドでの基盤染さは $1.5 \mathrm{~km}$ 以上となる。気象台断面では六甲山麓近傍で幾つかの断層が 近接して存在し、断層間が破砕帯となっている。気象台近傍断面で の反射法探査による結果 ${ }^{20} に$ 基づき、海側からの低角逆断層（元町 断層 ${ }^{20}$ ) と会下山断層に挟まれ隆起した台地上に神戸海洋気象台 (JMA) が位置するものと仮定する。会下山断層から須磨断層間の 破砕帯は成層構造を仮定した。気象台断面では和田岬断層は海岸線 位置までに現れないため、その存在は無視した。鹰取断面は三宮断 面と同様に六甲山麓で $600 \mathrm{~m}$ 程度基盤が落ち込み、海側に徐々に基 盤が深くなる構造とした。海岸線位置での基盤深度は約 $1.2 \mathrm{~km}$ で ある。三宮断面より西の地域では Vs $=500 \sim 600 \mathrm{~m} / \mathrm{s}$ の低速度層の 厚さが、灘地域に比べ比較的薄くなっている ${ }^{19}$ 。六甲山側の地盤

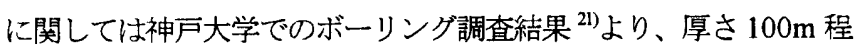
度の風化層 $(\mathrm{Vs}=1350 \mathrm{~m} / \mathrm{s})$ を基盤上に仮定した。

深部不整形地下構造への入射条件は、神戸側でのアスペリティ

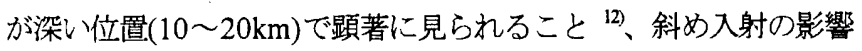

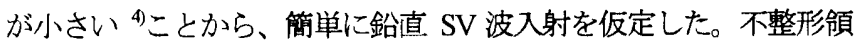
域は FEM でモデル化し、ほぼ成層領域と見なせる左右両端位膡に エネルギー伝達境界を設定する。計算対象とする振動数は 0 ～5 Hz とし、有限要素分割は $5 \mathrm{~Hz}$ で 1 波長 5 ポイント以上を目安に行った。

\section{3. 基盤波の評価}

\section{1 用いる観測記録と基盤波の評価方法}

神户市内で得られた観測記録を用いて、大阪層群上面位置や基 盤位置における露頭波（以下、これを基盤波と表記する。）を算定 する。地震波は液状化等による地震波動への影響の比較的少ない本 山小学校(MOT)、神戸大学(KBU)、莫合(FUK)、GL-83m位置のポー トアイランド(POI)、神戸海洋気象台(JMA)、鹰取(TKT)での観測記録 を用いた（Fig.1参照）。MOT、KBUは断面方向のN160 Eに、FUK、 POI、JMA、TKTは速度波形のオービットから決定した卓越方向を 主軸方向（それぞれN140 $\mathrm{E} 、 \mathrm{~N} 130^{\circ} \mathrm{E} 、 \mathrm{~N} 140^{\circ} \mathrm{E} 、 \mathrm{~N} 145^{\circ} \mathrm{E}$ ）とし変換

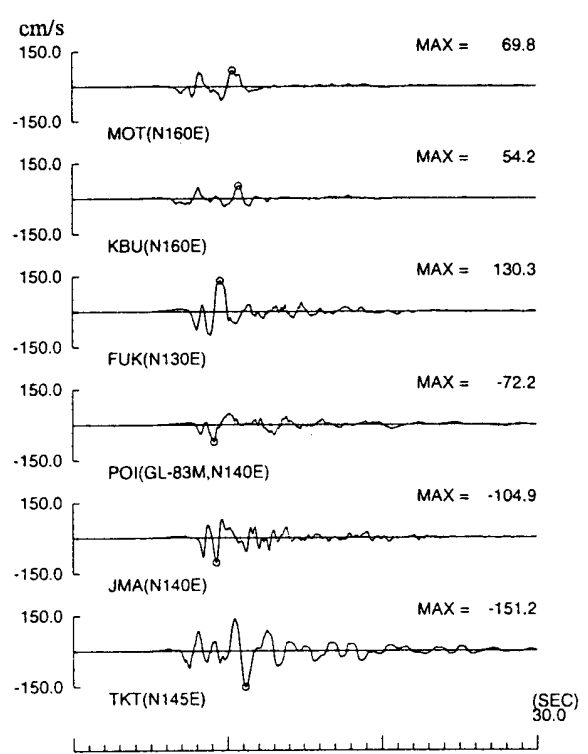

Fig.3 Velocity waveforms of recorded motions

した。POI(GL-83m)の記録に関しては地震計設置方向の推定誤差 ${ }^{22)}$ を考慮して変換した。各記録の主軸方向と断面の方向は若干異なる

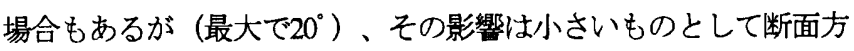
向の波形と見なした。用いた観測記録の速度波形をFig.3に示寸。

$\mathrm{KBU}$ では $\mathrm{V}_{\mathrm{s}}=850 \mathrm{~m} / \mathrm{s}$ 以下の表層地盤 ${ }^{21)}$ の影響を 1 次元等価線形解 析により、あらかじめ除去する。段差境界近傍に位置するMOTに 関しては、表層地盤と段差境界との連成により複雑な波動場となる ことが予想されるため、表層地盤を考慮した境界周辺の 2 次元FEM モデルを作成し直接基盤波を評価した。このとき岡本断面を基に作 成した既往のモデル14の゙は、段差境界より堆積地盤側にあるMOTの 位置が整合しなかったため、余震記録のシミュレーション解析を

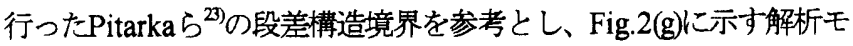
デルを用いた。MOT地点直下ではせん断波速度 $\mathrm{V}_{\mathrm{s}}=200 \mathrm{~m} / \mathrm{s}$ 、厚さ $20 \mathrm{~m}$ の表層地盤を大阪層群上に仮定した。FUK、POI、JMA、TKTは、 2 次元FEMモデルで考慮していない大阪層群上の軟弱表層地盤や不 整形地形の影響を受けるため、次で述べる方法によりこれらの影響 を除去し大阪層群上面での露頭波を評価した後、2 次元FEMによっ て基盤波を評価する。

\section{2 大阪層群上面位圈における露頭波の竍価}

FUK、POI、JMA、TKTの観測記録に対し、大阪層群上の軟弱表 層地盤や不整形地形の影響を取り除き、大阪層群上面での露頭波を 算出する。FUK、TKTではV $\mathrm{V}_{\mathrm{s}}=500 \mathrm{~m} / \mathrm{s}$ 以下の軟弱表層地盤の影響を 非線形時刻歴応答の反復法 ${ }^{29} に よ り$ 取り除いた。POIではGL-83m位 置での観測記録を含む本震時の鉛直アレ一記録より推定した最適な 等価地盤物性を用い、SHAKEにより GL-83m位置での露頭波を求め た。FU、POI、TKT各地点の地層モデルと解析に用いた初期せん 断波速度をFig.4に示す。POIの初期せん断波速度はPS検層結果 ${ }^{29}$ を、 FUK、TKTは各地点でのボーリングデータ ${ }^{20277}$ のN值を時松らの提案 式 ${ }^{289}$ により換算して求めた。地盤の非線形特性はRamberg-Osgood モデルを用い、非線形パラメータは現位膡試料による室内試験結果 に基づいて設定した。Fig.4にはPOIでの最適な等価せん断波速度も 併せて示した。JMAは高さ約 $20 \mathrm{~m}$ の高台に位置しその影響が 3 次元 


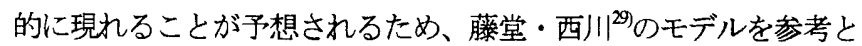
し、高さ $20 \mathrm{~m}$ 、直径 $80 \mathrm{~m}$ の円筒台地モデル（せん断波速度 $\mathrm{V}_{\mathrm{s}}=400 \mathrm{~m} / \mathrm{s}$ ）を大阪層群上に仮定し、軸対称hyperelement ${ }^{30}$ を用い てその影響を除去した。FUK、POI、JMA、TKTの大阪層群上面位 置での速度波形、擬似速度志答スペクトルをFig.5 とFig.6に示す。 4 波の最大速度值は $86 \sim 137 \mathrm{~cm} / \mathrm{s}$ となっており、地点毎にばらつき

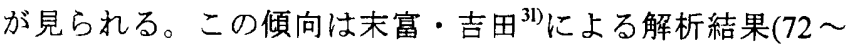
$109 \mathrm{~cm} / \mathrm{s}$ )でも同様に示されている。

\section{32 次元 F EMを用いた基盤波の算出}

深部不整形地下構造の 2 次元FEMモデルを用いて、FEM領域底面 での入射波を基盤波として算出する。このときKBUは神戸大学断面、 FUK、POIは三宮断面、JMAは気象台断面、TKTは鹰取断面の 2 次 元FEMモデルをそれぞれ用いる。基盤波に対する各地点での伝達関 数をFig.7に示す。KBU、MOT以外の地点では0.5秒以上の周期帯域 で基盤波に対し大きく増幅する傾向が見られる。他地点に比べ段差 境界より離れた位置にあるPOIは、成層地盤の増幅特性に後続の表 面波の影響が加わり、変動の大きい複雑な伝達特性を示す。Fig.8 とFig.9はFig.7.を用いて逆算した基盤波の速度波形と擬似速度灾答 スペクトルである。Table 2に観測記録、大阪層群上面での露頭波、 基盤波の最大速度值、最大加速度值を一覧にして示す。ただしPOI の基盤波の最大加速度值に関しては、Fig9の忘答スペクトルに見ら れるように他基盤波に比べ短周期成分が過大評価されているため、 3Hzカットで評価した。

観測記録で $54 \sim 151 \mathrm{~cm} / \mathrm{s}$ 、大阪層群上面位置で $86 \sim 137 \mathrm{~cm} / \mathrm{s}$ と地 点毎にばらつきが見られた最大速度値は、基盤位置では50〜 $60 \mathrm{~cm} / \mathrm{s}$ の同振幅レベルに収束する。基盤波の最大加速度值もTKTを 除くと350〜 390 cm/ $\mathrm{s}^{2}$ 程度となる。これらの值はMAを対象として

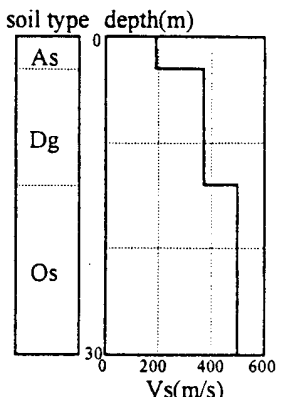

(a) FUK

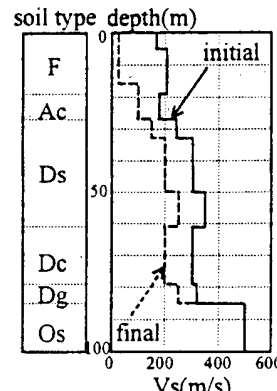

$\mathrm{Vs}(\mathrm{m} / \mathrm{s})$
(b)POI

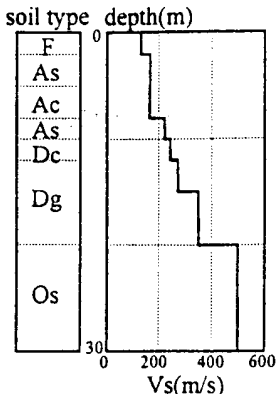

$\mathrm{Vs}(\mathrm{m} / \mathrm{s})$
(c) TKT
Fig.4 Soil models of soft surface layers at FUK, POI and TKT $\mathrm{em} / \mathrm{s}$
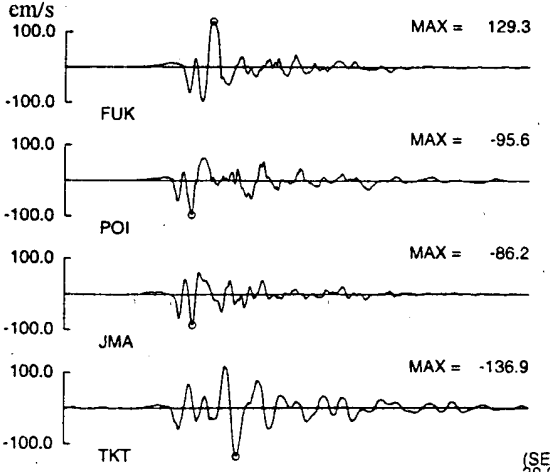

Fig.5 Deconvolved velocity waveforms on Osaka group
検討した川瀬・林 2 の結果とほぼ対応する。Fig.8の基盤波形に見ら れるようにMOTとKBUの基盤波形は2つの大きなパルス波（図中

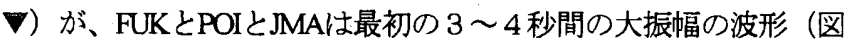
中下線部）がそれぞれ特徵的であり、各地点グループが比較的近接 していることから主要動部分は最大振幅、位相ともに類似した波形 となっている。大阪層群上面位置の态答スペクトルでは、特に 1 秒 以上の長周期領城で地点毎に大きく異なる振幅レベルを示すが、基 盤波はほぼ同じ振幅レベルとなる。これらより工学的基盤と考えら れる大阪層群上面での強震動でも、染部不整形地下構造の影響を強 く受けることが指摘される。

\section{4. 海岸線位固での観剆記録のシミュレーション}

算出した基盤波を用いて海側の地点での地震動を算定し観測記 録と比較する。対象とする地点はFig.1に示寸東神戸大橋(EKB)、六 甲アイランド(RKI)、神戸港湾事務所(KBH)である。最初に六甲山側

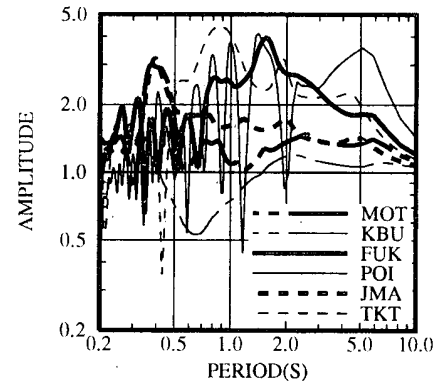

Fig.7 Transfer functions from bedrock motions

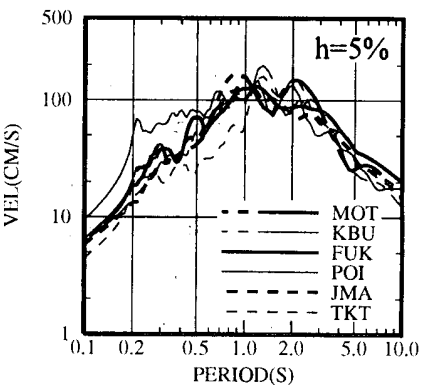

Fig.9 Pseudo velocity spectra of bedrock motions
Table 2 Peak velocities of recorded and deconvolved motions

\begin{tabular}{|c|c|c|c|}
\hline site & recondedmations & onOsagrap & bedrodmotions \\
\hline MOT & $70(458)$ & - & $53(370)$ \\
\hline KBU & $54(311)$ & - & $59(371)$ \\
\hline FUK & $131(854)$ & $129(752)$ & $49(372)$ \\
\hline POI(GL-83m) & $72(486)$ & $96(693)$ & $53\left(385^{*}\right)$ \\
\hline JMA & $104(835)$ & $86(621)$ & $55(357)$ \\
\hline TKT & $151(713)$ & $137(617)$ & $54(261)$ \\
\hline
\end{tabular}

( ) : peak accelerations, $5 \mathrm{~Hz}$ cut except $* 3 \mathrm{~Hz}$ cut

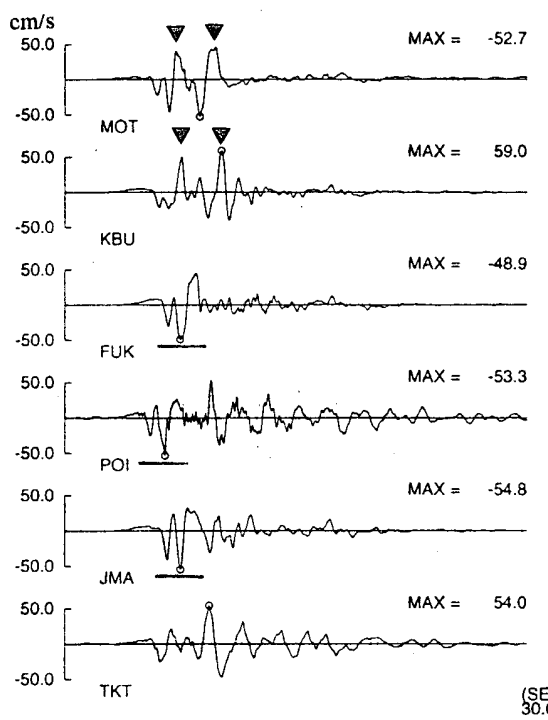

Fig.6 Pseudo velocity spectra of deconvolved motions on Osaka group
Fig. 8 Velocity waveforms of bedrock motions 


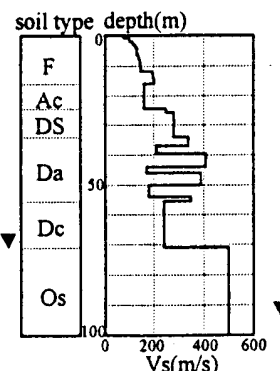

(a) $\mathrm{EKB}$

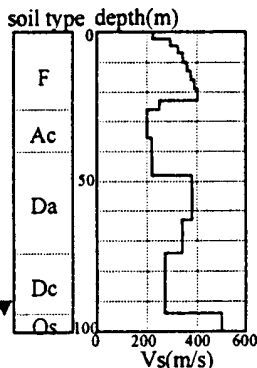

(b) RKI

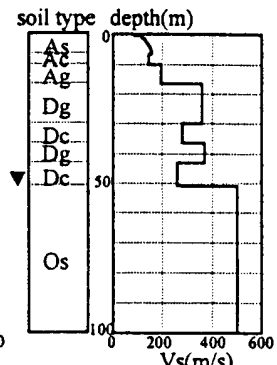

(c) $\mathrm{KBH}$
Fig.10 Soil models of soft surface layers at EKB, RKI and $\mathrm{KBH}$ sites ( $\boldsymbol{\nabla}$ : input level)

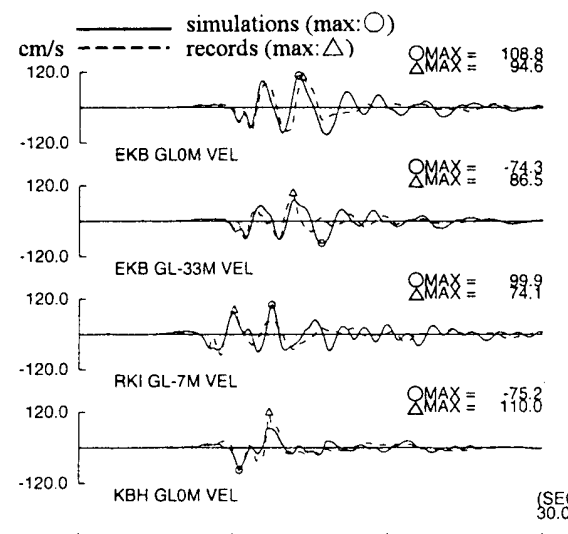

Fig.11 Comparison of simulated and recorded motions at EKB, RKI and KBH sites

に位置し各地点に近いMOT、KBU、JMAの基盤波を用い、2 次元 FEMにより大阪層群上面での地震波を算定する。このときEKBは岡 本断面 $\mathrm{x}=2.6 \mathrm{~km}$ 地点、 $\mathrm{RKI}$ は神戸大学断面 $\mathrm{x}=4.0 \mathrm{~km}$ 地点、 $\mathrm{KBH}$ は三 宫断面 $\mathrm{x}=2.1 \mathrm{~km}$ 地点の波形を用いる。次に大阪層群上に堆積する軟 弱表層地盤の非線形举動を考慮するため、各地点で1次元モデルを 設定し、上記の波形を上昇波として入力した時刻歴非線形解析を行 う。EKB、RKI、KBHの地層モデルと初期せん断波速度をFig.10に 示寸。初期せん断波速度の設定はEKBでは文献32)33)に、RKIでは文 献8)に基づき設定し、KBHでは基盤波の算定時と同様にN值 ${ }^{39}$ から の換算式を用いた。EKB、KBHではYUSAYUSAを用いた液状化解 析3゙を行ない、基喽直下が地盤改良され液状化の痕跡が少なかった RKIでは全応力解析を行なった。地盤の非線形パラメータは現位置 試料による室内試験結果や、室内詿験結果のない地層については各 土質に忘じた標準的な物性をを用いた。液状化パラメータはポート アイランドの液状化解析》で用いた液状化強度のうち当該土質等に 忘じた值を仮定した。

得られた速度波形を観測記録と比較してFig.11に示寸。EKB ${ }^{38) 、}$ $\mathrm{RKI}^{\circledR}$ ， $\mathrm{KBH}^{3 \mathrm{3})}$ の観測記録は主軸方向（それぞれN $145^{\circ} \mathrm{E} 、 \mathrm{~N} 150^{\circ} \mathrm{E} 、$ $\mathrm{N} 155^{\circ} \mathrm{E}$ ）に変換し比較する。 RKIの観測記録は40階建てのSRC構造 物の地下1階 (GL-7m) で得られているが、上部構造物との相互作 用の影響仯小さいものと仮定した。い゙れも最初の数秒間の主要動 部分に関しては算定波は観測記録と良く対応する。特にEKBの速度 波形ではGLOm、-33m ともに概ね良好に再現される。設定した地 盤モデル、解析手法・仮定等が正しく評価されているという条件の 下に限られるものの、これらの結果より算定した基盤波が妥当であ ることが期待できる。

\section{5. 大阪層群上面での最大応答値分布と被害分布との対応}

3. で評価した基盤波と断層に直交する 6 断面の 2 次元 FEM モ デルを用いて、大阪層群上面位置での地盤応答を評価する。岡本断 面では MOT、神戸大学、都賀川断面では KBU、三宫、気象台断面 では JMA、鷹取断面では TKT の基盤波を入射波として用いた。 Fig.12 に6 断面の加速度、速度波形の最大值分布を示す。図中○口 は当該地点の地表面位置での観測記録の最大值を示す。

いずれの断面でも段差境界位置から海側に $1 \mathrm{~km}$ 前後離九た領域 で地震動が増幅するのは共通であり、水平方向の最大加速度值は $800 \sim 1200 \mathrm{~cm} / \mathrm{s}^{2}$ 、最大速度值は 150 $200 \mathrm{~cm} / \mathrm{s}$ となる。最大值分 布の形状は深部地下構造により若干異なる。基盤深度が急激に低下 する岡本断面、神戸大学断面では最大忘答值の大きなピークが見ら れるのに対し、基盤深度が徐々に低下する都賀川断面では、最大忘 答值はなだらかな分布性状を示す。また基盤の段差が数䈯所見られ る気象台断面では、段差の位置に対応して最大忘答のピークが見ら れる。神戸大学断面の最大值分布は、地盤速度構造、厚さ等の仮定 はやや異なるものの源栄・承野によよる分布とほぼ同じ傾向を示寸。 一方、三宮断面では単一のピークを有する川瀬・林 ${ }^{2} の$ 分布に比べ、 やや複雑となり幾つかのピークが見られる。これは基盤が段差境界 より徐々に低下する構造となっていること、また和田岬断層で再び 段差構造を形成することが原因と考えられる。上下方向の応答は段 差境界位置で大きく励起されており、その最大値は水平方向の応答 と同程度となっている。

最大值分布で見られるピークを検討するため、神戸大学、都賀 川、三宮断面を例に取り、大阪層群上面での基盤波に対する伝達関 数、加速度芯答スペクトルの分布を Fig.13 に示寸。各断面の伝達 関数を見ると、卓越振動数に差はあるものの $\mathrm{x}=1.0 \mathrm{~km}$ 近傍で地震 動增幅が顕著となるのは共通して見られる。基盤が段差境界で急激 に低下し大阪層群の厚さがほぼ一定となる神戸大学断面で怯、横縞 の線に相当する 1 次元的な堌幅に、段差境界より励起され水平方向 に伝播する波動（右下がりの曲線に相当）が干涉する形の增幅特性 を示す。一方、基盤深度が徐々に低下寸る都賀川、三宮断面では神 戸大学断面に比べ複雑な增幅特性を示寸。加速度応答スペクトルを 見ると、神戸大学断面では $\mathrm{x}=1 \mathrm{~km}$ で約 $0.8 \mathrm{~Hz} 、 1.5 \mathrm{~Hz}$ の基盤波の 卓越成分が増幅し、これが大きなピークを形成する。一方、都賀川 断面では約 $1.5 \mathrm{~Hz}$ の基盤波の卓越成分の増幅が $\mathrm{x}=1.0 \mathrm{~km}$ に、約 $0.8 \mathrm{~Hz}$ の基盤波の卓越成分の増幅が $\mathrm{x}=2.5 \mathrm{~km}$ に現れ、これが最大

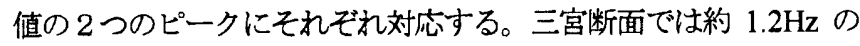
基盤波の卓越成分が増幅する領域 $\mathrm{x}=0.8 \mathrm{~km} 、 1.7 \mathrm{~km} 、 3.0 \mathrm{~km}$ がそ れぞれ最大值のピークに対志する。

Fig.12 には中央開発 ${ }^{39}$ (図中 CK) 、建築研究所 ${ }^{40}$ (同 BRI) 、 藤原ら ${ }^{41)}$ 、Akamatsu et al. ${ }^{4}$ による被害調查結果も、各断面におけ る最大忘答分布と比較して示した。 CK は木造と RC 造を対象とし た被害率であるが、調查断面が解析断面と一致しない断面では比較 的近い位置での結果を示す。BRI に関しては解析断面を挟む断層平 行方向の 3 4 ブロックで住宅用低層構造物の大破率を集計した結 果を、藤原らに関しては三宮、気象台断面での木造全壊率を 3 4 ブロックで集計した結果を示す。Akamatsu et al.は神戸大学断面で の木造建物の大破率である。同図には林ら ${ }^{43}$ が示した最大速度と被 害率の回帰式を用いて、大阪層群上面での最大速度から求めた結果 

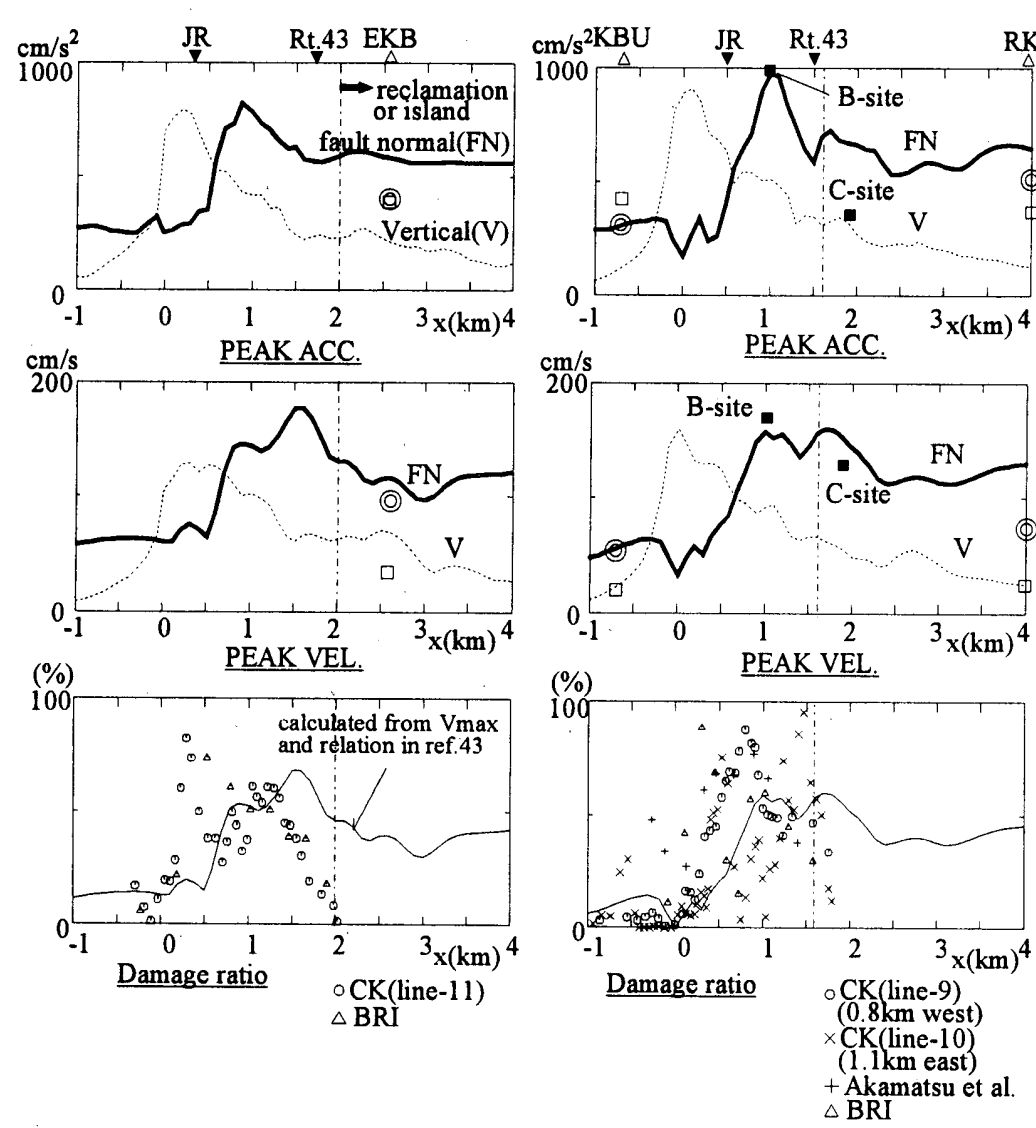

(a) Okamoto section

(b) Kobe Univ. section
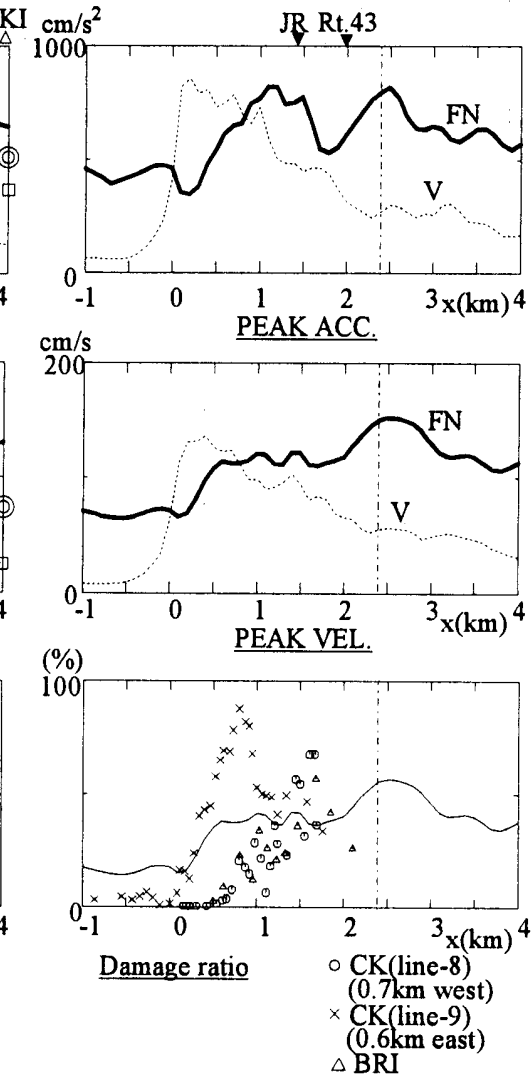

(c) Togagawa section
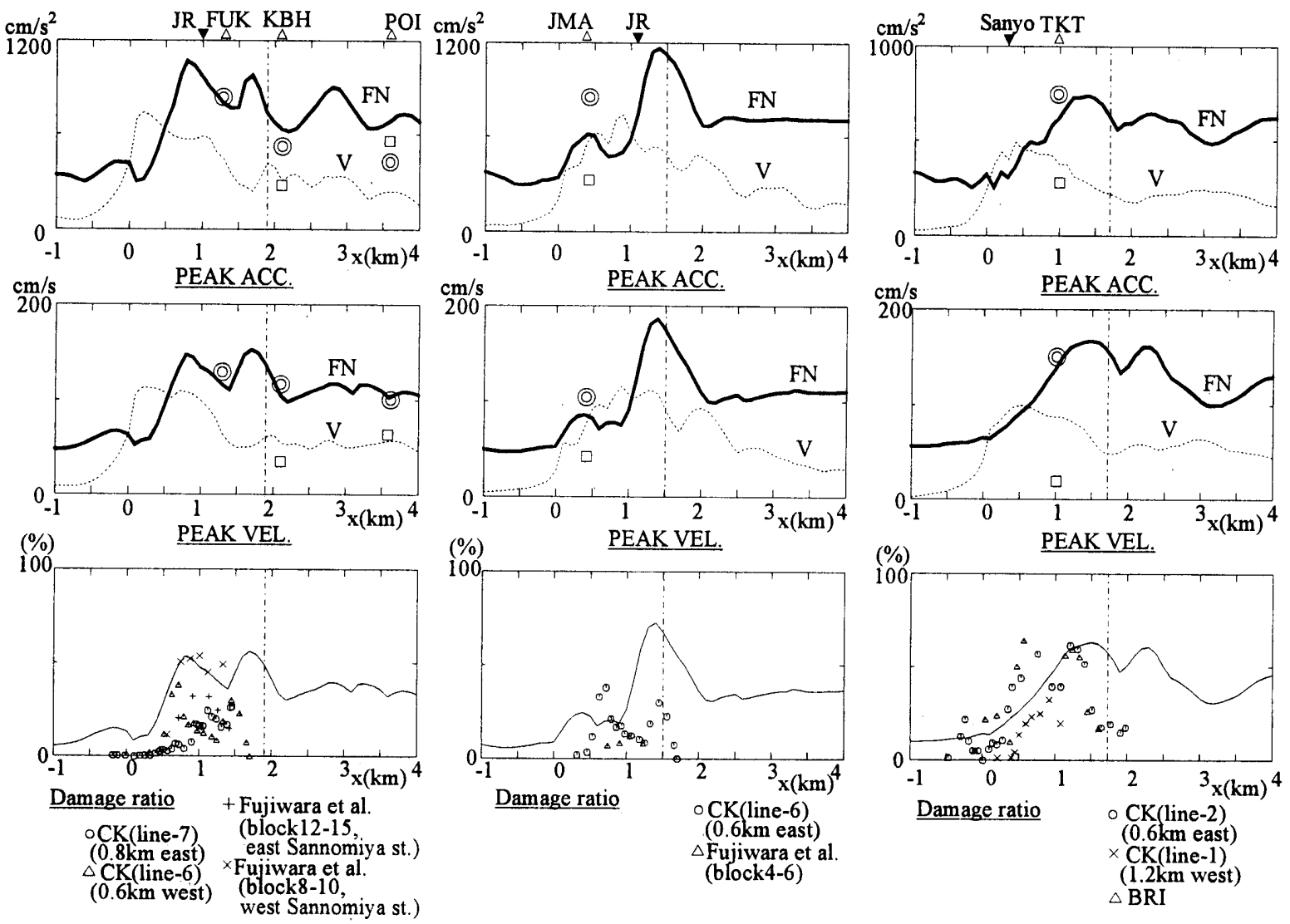

(d) Sannomiya section

(e) JMA section

(f) Takatori section

Fig.12 Distribution of peak responses of seismic motions on Osaka group and ratios of damaged structures 

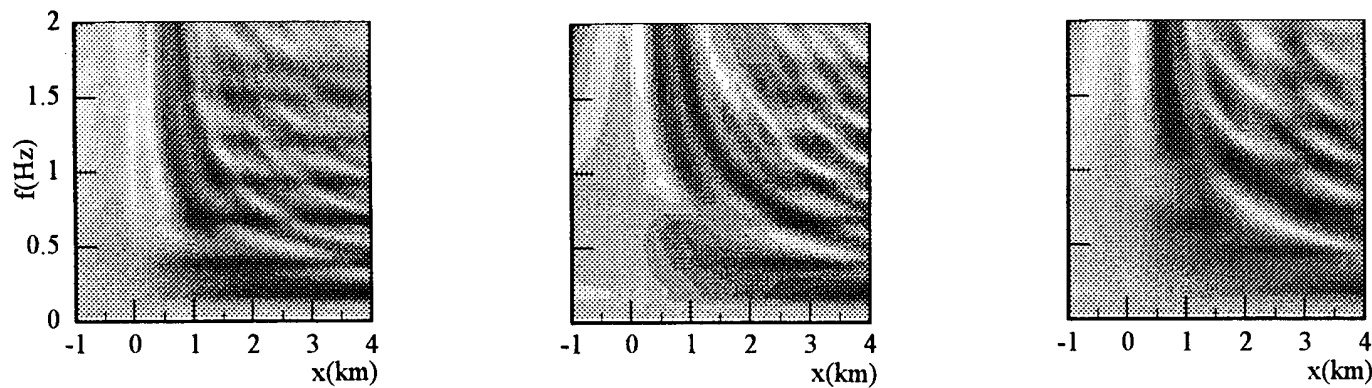

(a) Transfer functions from bedrock motion

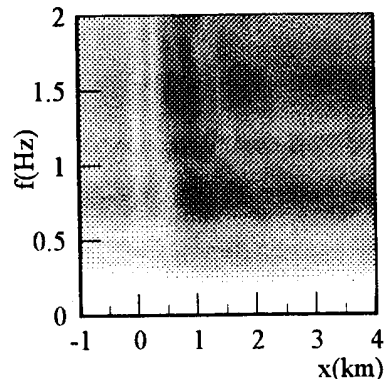

Kobe Univ. section

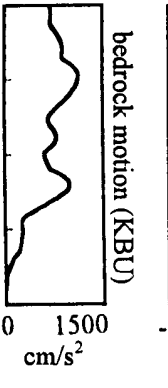

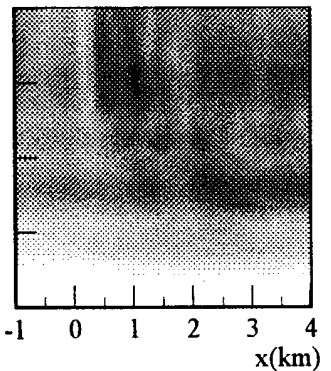

Togagawa section

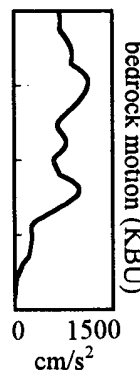

tra $(h=5 \%)$

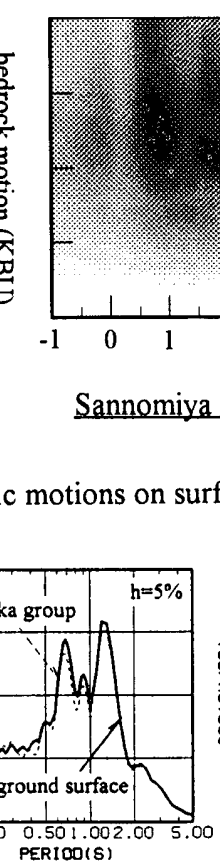

(a) B site

Fig. 14 Soil models of soft surface layers at B\&C sites

（算定被害率と呼ぶ。）も併せて示す。

各断面での被害率分布にはばらつきが見られるが、算定被害率 の分布は概ねその平均的な傾向を捕らえており、震災の帯地域では 大阪層群上面での最大速度により被害率を説明できるものと考える ことが出来る。大阪層群上面位置では最大加速度と最大速度は同様 な分布性状を示すことから、被害率分布と最大加速度分布を対応さ せることも可能であると思われる。都賀川断面では CK(line-9)の分 布がやや異なりむしろ神戸大学断面に近い性状を示すが、都賀川断 面と神戸大学断面の間での 3 次元的な基盤形状の変化の影響を受け ていることも考えられる。一方、埋立領域 (Fig.12 中、一点鎖線) 付近から海側では被害率は急激に小さくなり、最大速度から求めた 算定被害率は過大評価となる。埋立地、もしくは人工島部で液状化 した地点（EKB、KBH、POI）の地表面での観測記録の最大值を大 阪層群上面位置と比較すると、最大速度はほぼ同レベルであるが、 最大加速度は大阪層群上の軟弱表層地盤の影響により低減する。 Fig.1 に示寸神戸大学断面近くの 2 地点（B 地点、C 地点）での ボーリングデータから推定した地盤モデル49（Fig.14）を用いて、 軟弱表層地盤の非線形解析を行った。 B 地点は震災の带の中に、C 地点は埋立地域に位置し、軟弱表層地盤の層厚はそれぞれ $21 \mathrm{~m}$ 、 $61 \mathrm{~m}$ である。解析手法、モデル化等は文献 44)による。本検討で得 られた大阪層群上面位置の地震波を入力として用い、算定した地表

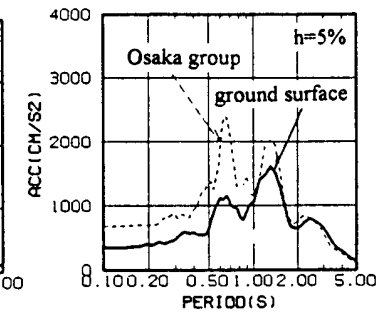

(b) C site
Fig.15 Acceleration response spectra of seismic motions at B\&C sites on both Osaka group and ground surface

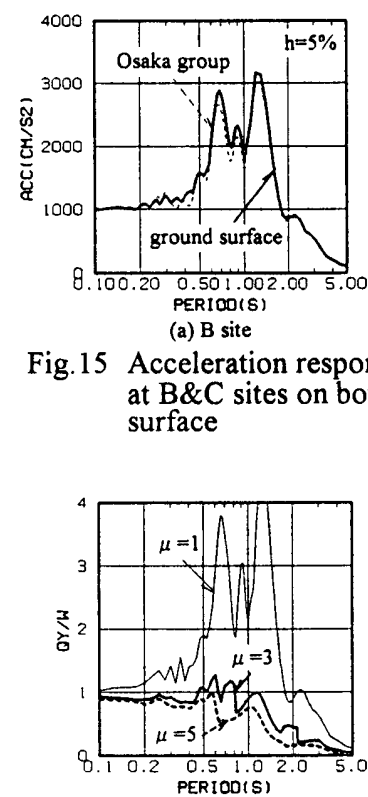

(a) B site $\mathrm{H}=2 \%$

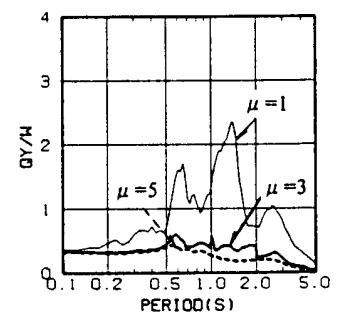

(b) $\mathrm{C}$ site $\mathrm{H}=2 \%$
Fig. 16 Strength demand spectra of ground motions at B\&C sites

面位置での最大加速度、速度を Fig.12(b)に印で示す。B 地点の最 大加速度、速度は大阪層群上面とほぼ同じであるが、C 地点では最 大加速度が最大速度に比べ急激に低下する。Fig.15 に両地点の大阪 層群上面、地表面位置での加速度忘答スペクトルを示す。C 地点で は 0.6 0.7 秒の周期成分が減少しており、これが最大加速度の低減 に影響するものと考えられる。

最大加速度と建物被害との関係を考察するために、B、C 地点で の地表面波形を用い、1 質点バイリニア弾塑性系における設定塑性 率 $\mu$ に対する必要耐力スペクトルを算定した。Fig.16 は塑性率 $\mu$ $=1,3,5$ に設定したときのベースシア係数であり、減衰定数は $2 \%$ 、塑 性後剛性注初期岡性の 0.01 倍である。弾性固有周期 0.5 秒以下の建 物の必要耐力は、 $\mu=3 、 5$ のいずれのケースでもほぼ最大加速度に 
よる慣性力に相当し、C地点の必要耐力は B地点の半分以下となる。 これより埋立地近傍での被害率の急激な低下は、軟弱表層地盤の影 響による最大加速度の低减に対忍する結果であるものと考えられる。

\section{6.まとめ}

神戸市内の東西に分布する断層直交 6 断面を対象とし、基盤波 の算定と地盤増幅特性の検討を行った。結果を以下にまとめる。

(1) 神戸市内 6 地点の観測記録を用いて、大阪層群上面位置での露 頭波や基盤波を評価した。大阪層群上面での露頭波の最大速度 值は 86〜 $137 \mathrm{~cm} / \mathrm{s}$ と地点毎にばらつきがみられるが、基盤波は $50 \sim 60 \mathrm{~cm} / \mathrm{s}$ とほぼ同振幅レベルに収束する。

(2) 基盤波と深部地下構造の 2 次元 FEM モデル、軟弱表層地盤の 1 次元モデルを用いて海岸線近くの3地点での強震記録のシミュ レーション解析を行った。その結果、計算波形と観測記録とは 概ね対芯し、設定した地盤モデル、解析手法・仮定等が正しく 評価されているという条件の下に限られるものの、算定した基 盤波が妥当であることが期待できる。

(3) 6つの断層直交断面にお引る大阪層群上面での最大忘答加速度、 速度分布を算定し、深部地下構造の形状の差異による地震動の 地盤増幅特性の変化を検討した。いずれの断面でも段差境界位 置から海側に $1 \mathrm{~km}$ 前後離れた領城で地震動が増幅するのは共通 に見られるが、樑部地下構造の形状により基盤からの増幅特性 が複雑に変化すること、基盤波の卓越周期との関係により最大 值分布のピーク位置が決定されることを示した。また震災の帯 地域では大阪層群上面での最大速度を用いて被害率を概ね説明 できること、埋立地域での急激な被害率低減は軟弱表層地盤に よる最大加速度の低減に対応することを確認した。

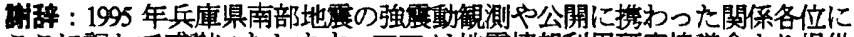
ここに記して感謝いたします。TKTは地霞情報利用研究協議会より提供 された JR 警報地震計 (鷹取駅、FD シリアル番号 R-053)によるものであ ります。また地盤調查や建物被害調查を通じ贵重な資料を残された各機 関の関係者の努力に敬意を表します。本論文を作成守るに当たり武村雅 之博士を始めとする鹿自小堀研究室の方々には有益な御助言を頂きまし た。

\section{考考文献}

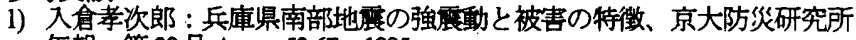
年報、第38 号A、p.53-67、1995

2）川瀬 博、林 康裕：兵庫県南部地震時の神戸市中央区での基盤波の 逆算とそれに基つく強動シミュレーション、日本建築学会構造系論 文集、第 480 量、p p.67-76、1996

3) 林康蓉、川瀬博 : 1995 年兵庫県南部地䈨における神戸市中央区の 地震動評価、日本建筑学会構造系論文集、第 481 号、po37-46、1996

4）源栄正人、永野正行 : 深部不整形地下構造を考虚した神戸市の地霞動 の増幅特性解析、日本建築学会構造系論文集、第 488 号、pp.3948、 1996

5) 藤田和夫 : 阪神地域活断層調査について、大阪湾の深部構造を考え る.-凟料集、pp.1-10、1996

6) 応用地誓、第 37 巻第 4 号、特集 - 兵庫県南部地展一応用地質学加らの

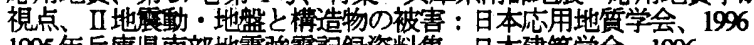

7) 1995 年兵庫県南部地震强震記録資料集、日本建築学会、1996

8) 六甲アイランド CITY、1995 年兵庫具南部地展の地震動観測記録と分 析 : 糟水ハウス, 1996

9) Kagawa, T., Irikúra K. and Yokoi I. : Restoring Clipped Records of Near-Field Strong Ground Motion During the 1995 Hyogo-ken Nanbu(Kobe), Japan Earthquake, J. Natural Disaster Science, Vol.18, No.1, pp.43-57, 1997

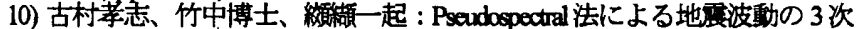
元鲇算、物理探查、第 49 巻第 6 量、pp.536-548、1996

11) 入倉孝资郎:阪神大磷災を引き起こした强震動、京都大学防災研究所 年報、第39号 A , p. 17-33、1996

12）武村雅之：どこま父解明されたか兵庫県南部地䅶の震源過程 その 1.
波形インバージョンによる結果、日本地震学会 1996 年度秋季大会、 A49

13) 永野正行 源学正人、山田有考: 深部不整形地下構造を考慮した神户 市の強震地動分布の推定、過大入力を受计る建築構造物の動的崩壊過 程の解朋シンホホジウム、日本建筑学会、pp9-16、1996

14) 永野正行、加藤研、大野 晋、古山田耕司：反射法結果に基つくく 次元モテルをを用いた神戸市灌地域の強鹿動シミュレーション解析、第 24 回地震工学研究発表会講演論文集、pp.77-80、1997

15) 石田宽、野沢貴、古屋伸二、高井剛、加藤研一丹羽正徳 : 神戸市街 地直下に拄ける基盤岩深度分布の推定、一队や長周期微動の水平/上 下スペクトル比に基つく評価一、日本建築学会構造系論文集、第 485 号、po.63-72、1996

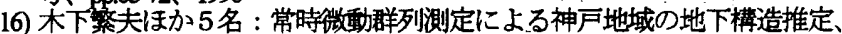
物理探查、第 49 卷第 6 号、 p p.452-458、1996

17) 小林登美ほか 5 名: 神市市東灘区に扔ける反射法探查、日本地震学会 1996 年度秋季大会、A38

18）香川敬生、澤田純男、岩崎好規、南荘淳 : 大阪堆積盆地におおる深部 地盤構造のモデル化、第22回地霜工学研究発表会, pp.199-202、1993

19) 岩見義男、神戸のまちと地盤、神戸新聞出版センター p.14、1987

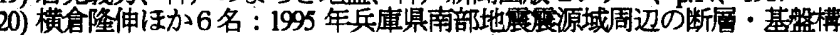
造について (概報)、物理探查、第 49巻第 6号、00.435-451、1996

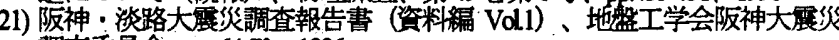
調查委員会、pp.6470、1996

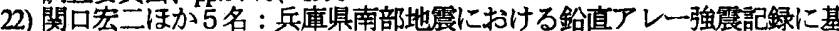

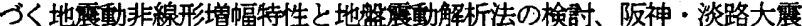
災に関する学術譜演会論文集、pp.109〜116、土木学会、1996

23) Pitarka, A., Irikura, K., Iwata, T. and Kagawa, T.: Basin Structure Effects in the Kobe Area Inferred from the Modeling of Ground Motions from Two Aftershocks of the January 17, 1995 HyogokenNanbu Earthquake, J. Phys. Earth, 44, pp.563-576, 1996.

24) 飛田 潤、杉村義広 : 鍴路気像台およ已釧路市内の地震動特性におけ る表層地盤の影響 1993 年釧路沖地鹿に関する総合シンポジウム、 pp.5964、日本建築学会、1994

25) 神戸市開発局 : ポートアイランド土質調查及び地震計設置業務報告書 1991

26) 岩見義男 : 神戸の地盤、神戸市企画局総合調查課、1980

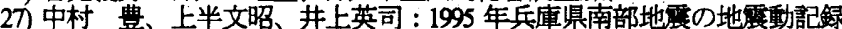
波形と分析（II）、 RR 地震情報 No23d，財団法人鉄道総合技術研究所 エレダス開登推准部、1996

28) 時松孝次、新井 洋、浅香美治: 微動観測から推定した神戸市住吉地 区の深部S 波速度構造と地餈動特性、日本建築学会構造系論文集、第 491 号、pp.37-45、1996

29）藤堂正喜、西川孝夫 : 兵庫県南部地震強震記録の建物応答人の影響に ついて、日本建策学会大会学術部演梗概集 B-2、pp203-204、1996

30) Kausel,E. and Roesset,J.M.: Semianalytic Hyperelement for Layered Strata J.Engrg.Mech, ASCE 103(4) pp.569-588, 1977

31) 末富岩雄、㐊田 望: 兵庫置南部地晨における地盤の非線形举動 (そ の2)、第 2 回阪神・淡路大度災に関寸る学術赫演会論文集、pp.65-72、 1997

32) 阪神高速湾岸線・東神戸大橋工事誌、阪神高速道路公団 1994

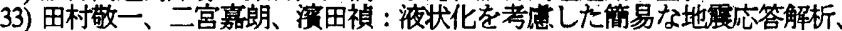
土木学会第51回年次学術满演会、III-A168、pp.336 337、1996

34) 稲富隆自ほか：1995 年兵庫県南部地震に之る 港湾施設等被害報告、港 湾技研資料、No.857、運輸省港湾技術研究所、1997

35) Ishihara K and Towhata I : One-Dimensional Soil Response Analysis during Earthquakes Based on Effective Stress Method, J. Faculty of Eng., Univ. of Tokyo, Vol.35, No.4, 1980

36) 原 “昭夫 : 土の動的変形特性と地盤の応答解析に関寸る研究、東京大 学学位請求論文、1980

37) 宮本裕司、酒向裕司、古山田耕司、三浦㹂治 : 1995 年兵庫県南部地霞

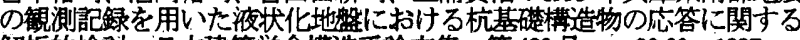
解析的検討、日本建築学会構造系論文集、第 493号、pp23-30、1997

38）土木研究所鲁報，第 64 号，土木構造物における加速度強鹿記録 (No21) : 建設省土木研究所、1995

39) 中央開発株式会社: 1995 年兵庫県南部地震 - 阪神大震災災害调查報告 書、1995

40) 建設省建築研究所 : 平成 7 年兵庫県南部地被害調查最終報告書 1996

41) 藤原悌三、鈴木祥之、北原昭男、鈴木 有 : 地震に強い町づくりをめ さして、平成 7 年度日本建策学会近幾支部研究報告集、pp233-236、 1995

42) Akamatsu, J., Morikawa, $\mathrm{H}$, Saito, $\mathrm{H}$ and Jido, M. Relation Between the Distribution of Damage Caused by the 1995 Hyogoken-Nambu Earthquake and Ground Vibration Characteristics Inferred from Microseisms, Journal of Natural Disaster Science, Vol.16, No.2, pp.6370,1995

43）林 康俗、宫腰漳一、田村和夫、川瀬 博 : 1995 年兵庫県南部地震の 低層建物被害率に基つく最大地動速度の推定、日本建築学会粠造系論 文集、第 494 号、pp.5966、1997.

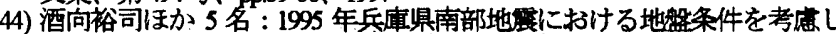
た構造物の地餅応答解析 (その 1) 神戸大学〜六甲アイランドでの表 屏地般の違いによる構造物の応答、1995 年度日本建築学会関東支部研 究報告集、pp.65-68、1996

(1997年9月10日原稿受理，1998年3月16日採月決定) 